\title{
Influence of Planting Geometry and Nitrogen Levels on Growth and Yield of Rice (Oryza sativa L.) under Eastern Uttar Pradesh Condition
}

\author{
Pradeep Rajput $^{1 *}$, A. K.Singh ${ }^{1}$, Ravindra Kumar Rajput ${ }^{2}$ and Prithvi Raj ${ }^{1}$ \\ ${ }^{1}$ Department of Agronomy, Acharya Narendra Deva University of Agriculture \& Technology, \\ Ayodhya, U.P., India \\ ${ }^{2}$ Department of Soil Science \& Agricultural Chemistry, Matter specialist (soil science), \\ KVK Mathura, U.P., India, India \\ *Corresponding author
}

\section{A B S T R A C T}

\section{Keywords}

Planting geometry,

Growth, Yield,

Nitrogen levels,

Rice, Dry matter,

Flowering and

Harvest Index.

\section{Article Info}

Accepted:

20 January 2020

Available Online:

10 February 2020
Field experiment was conducted during kharif-2017 at Agronomy Research Farm, Narendra Deva University of Agriculture and Technology, Narendra Nagar, Kumarganj, Faizabad, Uttar Pradesh, to study the effect of planting geometry and nitrogen levels on growth of rice (Oryza sativa L.). In this experiment, 4 planting geometry $(15 \times 10 \mathrm{~cm}, 15 \times 15 \mathrm{~cm}, 20 \times 10 \mathrm{~cm}$ and $20 \times 15 \mathrm{~cm})$ and 4 Nitrogen levels $(0$, 60,120 and $180 \mathrm{~kg} \mathrm{ha}^{-1}$ ) were tested in SPD with 3 replications. The crop received a total rainfall of $804.9 \mathrm{~mm}$ while the evaporation was $126.1 \mathrm{~mm}$ during the entire crop season. The results showed that the plant height, number of tillers $\mathrm{m}^{-2}$, leafarea index and dry matter accumulation $\mathrm{m}^{-2}$, being at par with $20 \times 15 \mathrm{~cm}$ spacing were significantly higher under $20 \times 10 \mathrm{~cm}$ than rest of the planting geometry. Nitrogen is also responsible for more leaf area and dry matter production due to higher rate of cell division and cell elongation. The application of nitrogen @ 120 $\mathrm{kg} \mathrm{N} \mathrm{ha}{ }^{-1}$, being at par with $180 \mathrm{~kg} \mathrm{~N} \mathrm{ha}^{-1}$ significantly improved the plant height, number of tillers $\mathrm{m}^{-2}$, leaf area index and dry matter accumulation $\mathrm{m}^{-2}$ than rest of the Nitrogen levels. The highest grain and biological yields were also noticed at $20 \times 10 \mathrm{~cm}$ spacing and $180 \mathrm{~kg} \mathrm{~N} \mathrm{ha}^{-1}$.

\section{Introduction}

Rice (Oryza sativa L.) is a most important cereal crop, grown under semi-aquatic condition and mostly under submergence or variable ponding conditions. It is a most important staple food of about more than $60 \%$ of total world population. Rice is a nutritious cereal crop, mainly used for human consumption. It is the main source of energy and is an important source of protein providing substantial amounts of the recommended nutrients intake of zinc and niacin. Planting geometry of a crop affects the interception of solar radiation, crop canopy coverage, dry matter accumulation and crop 
growth rate (Anwar et al., 2011). The closer planting geometry causes competition among plants for light, water and nutrients which consequently slowed down the crop growth. Optimum planting geometry ensures the proper growth of aerial as well as underground plant parts by efficient utilization of solar radiation, nutrients and water (Miah et al., 1990). Nitrogen is also responsible for more leaf area and dry matter production due to higher rate of cell division and cell elongation. Inadequate nitrogen application adversely affects the grain production while excess nitrogen may lead to relatively higher crop growth. The height of a rice plant is positively correlated to the length of the maturation cycle. A taller plant is more susceptible to lodging and responds less to nitrogen application (Tanaka et al., 1966).

Increasing the nitrogen application level could significantly increase the rice production within limits. The highest nitrogen uptake is observed at the tillering stage followed by the young panicle developmental stage. Both planting geometry and nitrogen levels are major causes of growth reduction in rice, which also affect its dry matter and tillers production and ultimately the yield. Salahuddin et al., (2009) the lowest number of grains/panicle was given by $0 \mathrm{~kg} \mathrm{~N} / \mathrm{ha}$ irrespective of plant spacing. Grain yield/ha increased with increasing level of nitrogen up to $150 \mathrm{~kg} / \mathrm{ha}$ irrespective of plant spacing. Keeping above points in mind the present investigation was conducted in rice.

\section{Materials and Methods}

The experiment was conducted during kharif2017 at Agronomy Research Farm of NDU A\&T, Kumarganj $\left(26.47^{0} \mathrm{~N}\right.$ latitudes, $82.12^{0}$ E longitudes and 113 meters above mean sea level), Faizabad, U.P. (India). The field was well drained, leveled and having good soil conditions. The soil of the experimental field was silt loam in texture with $\mathrm{pH}$ of 8.10 , low in organic carbon $(0.43 \%)$ and available nitrogen $\left(160 \mathrm{~kg} \mathrm{ha}^{-1}\right)$, medium in phosphorus $\left(16.5 \mathrm{~kg} \mathrm{ha}^{-1}\right)$ and potassium $\left(260 \mathrm{~kg} \mathrm{ha}^{-1}\right)$. Four planting geometry viz., $15 \times 10,15 \times 15$, $20 \times 10$ and $20 \times 15 \mathrm{~cm}^{2}$ and 4 Nitrogen levels( $0,60,120$ and $180 \mathrm{~kg} \mathrm{ha}^{-1}$ ) were tested in a split-plot design, keeping as main and subplots, respectively with 3 replication. The gross and net plot size was $6.0 \mathrm{~m} \times 3.0 \mathrm{~m}$ and $4.8 \mathrm{~m} \times 2.40 \mathrm{~m}$, respectively.

During the crop season weekly mean minimum and maximum temperature ranged from 16.7 to $28.7^{\circ} \mathrm{C}$ and 29.9 to $37.8^{\circ} \mathrm{C}$, respectively. The total rainfall and evaporation during the entire crop season was 804.9 and $126.1 \mathrm{~mm}$, respectively. However, the diurnal variation among relative humidity and evaporation rate was 43.5 to 86.1 per cent and 4.3 to $7.2 \mathrm{~mm}$, respectively.

The standard procedure was followed in rising of the seedlings in the nursery. Healthy and bold seeds of rice variety NDR-359 were used @ $40 \mathrm{~kg} \mathrm{ha}^{-1}$ for nursery rising in puddled soil. Transplanting was done as per treatment with 25 days old plants and 2seedlings/hill was used for transplanting. Phosphorus and potassium was applied @60 and $40 \mathrm{~kg} \mathrm{ha}^{-1}$ through SSP $\left(16 \% \mathrm{P}_{2} \mathrm{O}_{5}\right)$ and Muriate of potash $\left(60 \% \mathrm{~K}_{2} \mathrm{O}\right)$ as basal, at the time of pudding/leveling of the field, respectively. The nitrogen was applied through urea $(46 \% \mathrm{~N})$, as per treatment. Zinc sulphate $(21 \% \mathrm{Zn})$ was also applied @ $25 \mathrm{~kg}$ $\mathrm{ha}^{-1}$ as micro-nutrient in the rice field at the time of pudding.

The half dose of nitrogen was applied before transplanting of seedlings, plot wise and the rest amount of nitrogen was top-dressed in two equal splits first at 30DAT (tillering stage) and second at 55 DAT (panicle initiation stage). During the year of experimentation, there were occurrence of 
sufficient rains during vegetative stage, however, there was occasional moisture stress during reproductive phase, hence 3 irrigations were given at different stages viz., flowering, milking and grain filling stage of crop growth. Data were subjected to analysis of variance (ANOVA) using Online Statistical Analysis Package (OPSTAT, Computer Section) at 5\% level of significance $(\mathrm{P}=0.05)$.

\section{Results and Discussion}

\section{Growth attributes}

The maximum plant height $(106.0 \mathrm{~cm})$ was observed with wider spacing of $20 \mathrm{~cm} \times 10$ $\mathrm{cm}\left(\mathrm{S}_{3}\right)$ followed by $\mathrm{S}_{4}$ i.e. $20 \mathrm{~cm} \times 15 \mathrm{~cm}$ $(102.2 \mathrm{~cm})$, although there was no significant difference between them. However, the shortest plants $(93.5 \mathrm{~cm})$ were recorded by $\mathrm{S}_{1}$ planting geometry. The tallest plants were noticed with wider planting geometry $\left(\mathrm{S}_{3}\right)$ as compared to closer spacing $\left(\mathrm{S}_{2}\right.$ and $\left.\mathrm{S}_{1}\right)$ because of creation of an optimum condition for light interception, water and nutrient consumption that leads to lesser competition among plants. Similar results were also found by Devi and Sumathi (2011) and Bhowmik et al., (2012). It is evident from the results that plant height increased with the increasing level of $\mathrm{N}$ from 0 to $180 \mathrm{~kg} \mathrm{ha}^{-1}$, irrespective of planting geometry. Regarding the nitrogen levels, the maximum plant height $(112.7 \mathrm{~cm})$ was recorded with highest level of nitrogen $\left(180 \mathrm{~kg} \mathrm{ha}^{-1}\right)$, though statistically at par with $\mathrm{N}_{2}(109.9 \mathrm{~cm})$, receiving $120 \mathrm{~kg}$ nitrogen ha ${ }^{-1}$ and highly significant to $\mathrm{N}_{1}(94.5 \mathrm{~cm})$ and $\mathrm{N}_{0}$ $(79.0 \mathrm{~cm})$, receiving $60 \mathrm{~kg}$ nitrogen $\mathrm{ha}^{-1}$ and 0 $\mathrm{kg}$ nitrogen ha ${ }^{-1}$ respectively.

The increased plant height with increasing nitrogen levels might be attributed to the role of nitrogen which encourage and improve plant growth and accelerate cell division which was reflected in the increased plant height (Mohadesi et al., 2011). Singh and Sharma (1987) also reported that application of $180 \mathrm{~kg} \mathrm{~N} \mathrm{ha}{ }^{-1}$ resulted in higher plant height of rice.

Table.1 Effect of planting geometry and nitrogen levels on growth attributes of rice

\begin{tabular}{|c|c|c|c|c|}
\hline Treatments & $\begin{array}{c}\text { Plant height }(\mathbf{c m}) \\
\text { (At harvest) }\end{array}$ & $\begin{array}{c}\text { Tillers } \mathbf{( m}^{-2} \text { ) } \\
\text { (At harvest) }\end{array}$ & $\begin{array}{c}\text { LAI } \\
\text { (At 90 DAT) }\end{array}$ & $\begin{array}{c}\text { DMA }\left(\mathbf{g ~ m}^{-2}\right) \\
\text { (At harvest) }\end{array}$ \\
\hline \multicolumn{2}{|c|}{ Planting geometry (cm) } & & & \\
\hline $\mathbf{1 5 x 1 0}$ & 93.5 & 291.4 & 3.5 & 1099 \\
\hline $\mathbf{1 5 x 1 5}$ & 95.4 & 297.6 & 3.7 & 1177 \\
\hline $\mathbf{2 0 x 1 0}$ & 106.0 & 331.7 & 4.2 & 1298 \\
\hline $\mathbf{2 0} \mathbf{x 1 5}$ & 102.2 & 319.3 & 3.9 & 1236 \\
\hline $\mathbf{C D}$ at 5\% & 8.7 & 26.9 & 0.4 & 111 \\
\hline Nitrogen levels $\left(\mathbf{k g ~ h a}^{-\mathbf{1}}\right)$ & & & \\
\hline $\mathbf{0}$ & 79.0 & 248.0 & 3.1 & 893 \\
\hline $\mathbf{6 0}$ & 94.5 & 294.5 & 3.8 & 1145 \\
\hline $\mathbf{1 2 0}$ & 109.9 & 344.1 & 4.2 & 1235 \\
\hline $\mathbf{1 8 0}$ & 112.7 & 356.4 & 4.3 & 1337 \\
\hline CD at 5\% & 5.7 & 18.0 & 0.2 & 70 \\
\hline
\end{tabular}


Table.2 Effect of planting geometry and nitrogen levels on yields of rice

\begin{tabular}{|c|c|c|c|}
\hline Treatments & $\begin{array}{c}\text { Grain yield } \\
\left(\mathbf{q h a}^{-\mathbf{1}}\right)\end{array}$ & $\begin{array}{c}\text { Straw yield } \\
\left(\mathbf{q h a}^{-\mathbf{1}}\right)\end{array}$ & Harvest index (\%) \\
\hline \multicolumn{2}{|c|}{ Planting geometry $(\mathbf{c m})$} & & \\
\hline $\mathbf{1 5 x 1 0}$ & 46.2 & 63.7 & 41.4 \\
\hline $\mathbf{1 5 x 1 5}$ & 48.9 & 68.7 & 41.3 \\
\hline $\mathbf{2 0 x 1 0}$ & 54.0 & 75.7 & 41.8 \\
\hline $\mathbf{2 0} \mathbf{x 1 5}$ & 51.7 & 71.9 & 41.6 \\
\hline CD at 5\% & 4.4 & 6.1 & NS \\
\hline Nitrogen levels $\left(\mathbf{k g ~ h a}^{-\mathbf{1}}\right)$ & & \\
\hline $\mathbf{0}$ & 35.1 & 54.1 & 39.3 \\
\hline $\mathbf{6 0}$ & 45.2 & 69.2 & 39.5 \\
\hline $\mathbf{1 2 0}$ & 51.7 & 71.8 & 41.8 \\
\hline $\mathbf{1 8 0}$ & 56.7 & 76.9 & 42.4 \\
\hline CD at 5\% & 3.1 & 4.3 & NS \\
\hline
\end{tabular}

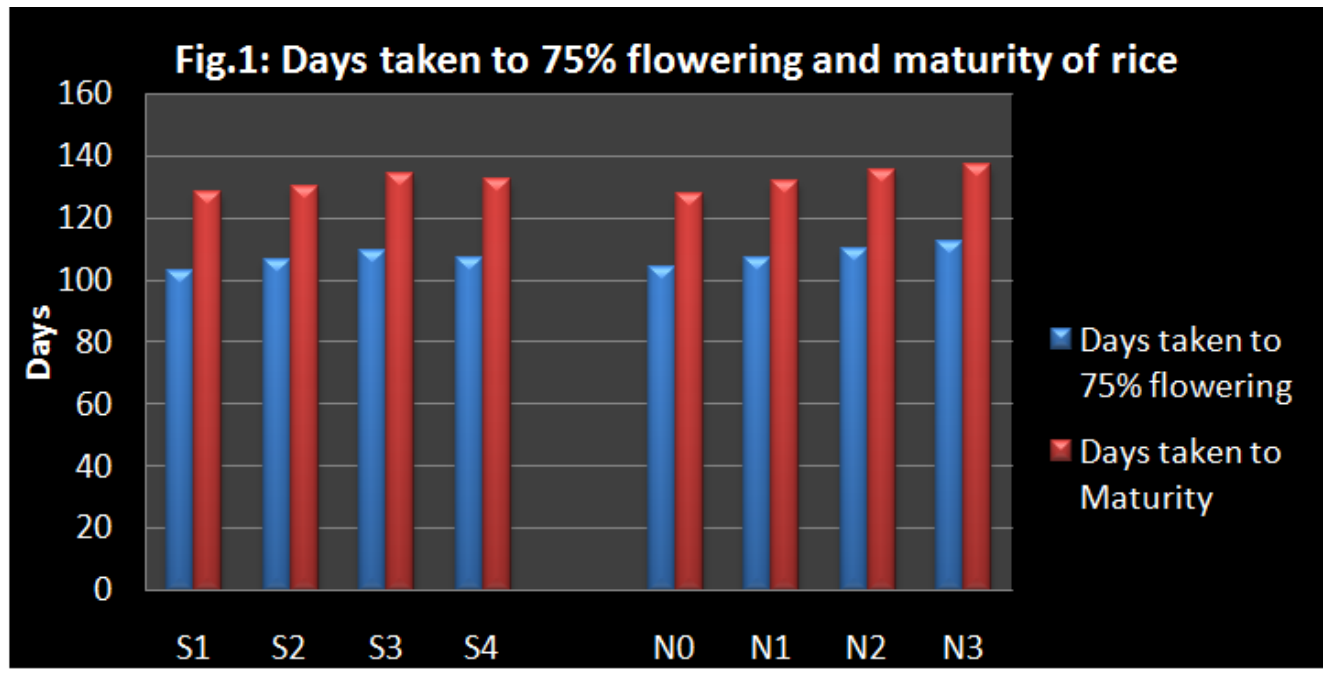

Fig.1 Days taken to $75 \%$ flowering and maturity of rice

Wider planting geometry $\left(\mathrm{S}_{3}\right)$ resulted into maximum tillers $\mathrm{m}^{-2}$ (331.7) which was at par with $\mathrm{S}_{4}\left(319.3 \mathrm{~m}^{-2}\right)$ and significantly more than the other planting geometry. Among the nitrogen levels, maximum tillers $\mathrm{m}^{-2}$ (356.4) were recorded under $\mathrm{N}_{3}$ being at par with 120 $\mathrm{kg} / \mathrm{ha}\left(\mathrm{N}_{2}\right)$ (344.1) and significantly higher over rest of the treatments. Similar results were also observed by Gupta et al., (2014) and Mahato and Adhikari (2017) in rice.

Leaf area and dry matter accumulation also influenced by different planting geometry and nitrogen levels at 90 DAT and harvesting, respectively. Wider planting geometry $(20 \mathrm{~cm}$ $\mathrm{x} 10 \mathrm{~cm}$ ) resulted into maximum values of both leaf area index and dry matter accumulation which was at par with $(20 \mathrm{~cm} \mathrm{x}$ $15 \mathrm{~cm}$ ) and highly significant with the other planting geometry. This treatment $\left(\mathrm{S}_{3}\right)$ had 18.1 and $10.2 \%$ more dry matter accumulation over $S_{1}$ and $S_{2}$, respectively.

The maximum leaf area and dry matter accumulation was recorded with $180 \quad\left(\mathrm{~N}_{3}\right)$ being at par with $120 \mathrm{~kg}^{-1}\left(\mathrm{~N}_{2}\right)$ and 
significantly higher over rest of the treatments. This might be due to the role of nitrogen in cell division and elongation that improves the plant height and photosynthetic area which led to higher LAI and DMA in these treatments. Similar results were also observed by Wang Hai Qin (2007) and Yadav at al. (2016).

\section{Days taken to $75 \%$ flowering and maturity of rice}

Various planting geometry had significant effect on days taken to $75 \%$ flowering. The highest days (109.5) were taken to attain $75 \%$ flowering under $\mathrm{S}_{3}$ and lowest days (103.2) were taken under $15 \mathrm{~cm} \times 10 \mathrm{~cm}\left(\mathrm{~S}_{1}\right)$ spacing. Various nitrogen levels had significant effect on days to $75 \%$ flowering.

The maximum days (112.5) were taken to $75 \%$ flowering under $180 \mathrm{~kg} \mathrm{~N} \mathrm{ha}^{-1}\left(\mathrm{~N}_{3}\right)$ and minimum days (104.5) were taken under $0 \mathrm{~kg}$ $\mathrm{N} \mathrm{ha}^{-1}$ (control). The crop took highest days (134.5) to attain maturity under wider spacing $\left(\mathrm{S}_{3}\right)$ and lowest days (128.5) were taken under $\mathrm{S}_{1}$ treatment. Among nitrogen levels the maximum days (137.4) were taken to attain maturity with $180 \mathrm{~kg} \mathrm{~N} \mathrm{ha}\left(\mathrm{N}_{3}\right)$ and minimum days (128.1) under $0 \mathrm{~kg} \mathrm{~N}$ ha $^{-1}$ $\left(\mathrm{N}_{0}\right)$.

\section{Grain yield}

A spacing of $20 \mathrm{~cm} \times 10 \mathrm{~cm}$ produced higher grain yield (54.0 $\left.\mathrm{qha}^{-1}\right)$ as compared to wider spacing $20 \mathrm{~cm} \mathrm{x} 15 \mathrm{~cm}\left(51.7 \mathrm{qha}^{-1}\right)$. However, very close spacing $S_{1}(15 \mathrm{~cm} \times 10 \mathrm{~cm})$ was undesirable for obtaining higher yield due to more competition and less availability of resources. Although, the pace of increment was14.4 and $4.2 \%$, respectively.

Further Wells and Faw (1978) reported that close spacing decrease the light interception and $\mathrm{CO}_{2}$ assimilation which in turn limit the rice yield. Namba (2003) reported that the increase in grain yield with optimum plant spacing might be attributed to increased number of tillers per unit area and filled grains per panicle after which plant growth slows down if it exceed the optimum level.

Each successive application of $60 \mathrm{~kg}$ nitrogen in rice resulted into significant improvement in grain yield upto $180 \mathrm{~kg}$ Nha-1. Though, the highest grain yield $\left(56.7 \mathrm{qha}^{-1}\right)$ was obtained with $180 \mathrm{~kg} \mathrm{~N} \mathrm{ha}^{-1}\left(\mathrm{~N}_{3}\right)$ which was statistically superior over $\mathrm{N}_{2}\left(51.7 \mathrm{qha}^{-1}\right), \mathrm{N}_{1}\left(45.2 \mathrm{qha}^{-1}\right)$ and $\mathrm{N}_{0}\left(35.1 \mathrm{qha}^{-1}\right)$. This treatment out fielded control, $\mathrm{N}_{1}$ and $\mathrm{N}_{2}$ by 21.6, 11.5 and $5.0 \mathrm{qha}^{-1}$, respectively. It was due to better nutrient uptake leading to higher dry matter production and its translocation towards sink leading to increased percentage of filled grains and number of tillers $\mathrm{m}^{-2}$ (Mandal et al., 1986).

\section{Straw yield}

A spacing of $20 \mathrm{~cm} \times 10 \mathrm{~cm}\left(\mathrm{~S}_{3}\right)$ recorded highest straw yield $\left(75.7 \mathrm{qha}^{-1}\right)$ as compared to closer spacing $\left(\mathrm{S}_{1}\right)\left(63.07 \mathrm{qha}^{-1}\right)$ and wider spacing $\left(\mathrm{S}_{4}\right)\left(71.9 \mathrm{qha}^{-1}\right)$ which might be due to reduce plant height and lesser plant population respectively. Similar observation was reported by Mahato et al., (2006). Maximum straw yield (76.9 $\left.\mathrm{qha}^{-1}\right)$ was recorded with $180 \mathrm{~kg} \mathrm{ha}^{-1}$ nitrogen $\left(\mathrm{N}_{3}\right)$ but was statistically at par with $\left(\mathrm{N}_{2}\right)\left(71.8 \mathrm{qha}^{-1}\right)$ followed by $\left(\mathrm{N}_{1}\right) \quad\left(69.2 \mathrm{qha}^{-1}\right)$ and $\left(\mathrm{N}_{0}\right)$ $\left(54.1 \mathrm{qha}^{-1}\right)$. This might be due to vigorous growth with increase in $\mathrm{N}$ level resulted in higher straw yield (Chopra and Chopra, 2004). Planting density greatly influenced the straw yield. However, the interaction effects were not significant. The increase in yield of rice due to $\mathrm{N}$ fertilization was attributed directly by the significant improvement of all the yield attributing traits viz. tiller $\mathrm{m}^{-2}$, filled grains panicle ${ }^{-1}$ and test weight (Banerjee and Pal, 2011). 


\section{Harvest index}

The harvest index was not significantly influenced either by the spacing or by nitrogen application, though it was varied from 41.3-41.8 and 39.3-42.4\%, respectively.

Therefore, it can be concluded that treatment combination of $180 \mathrm{~kg}$ nitrogen $\mathrm{ha}^{-1}$ along with planting geometry of $20 \mathrm{~cm} \mathrm{x} 10 \mathrm{~cm}$ could be recommended for cultivation of Transplanted rice in eastern Uttar Pradesh.

\section{References}

Anwar M.P., Juraimi A.S., Puteh A., Selamat A., Man A. and Hakim M.A. (2011) Seeding method and rate influence on weed suppression in aerobic rice. African J Biotechnol 10(68): 1525915271.

Bhowmik, S. K., Sarkar, M. A. R. and Zaman, F. 2012.Effect of spacing and number of seedlings per hill on the performance of aus rice $\mathrm{cv}$. NERICA 1 under dry direct seeded rice (DDSR) system of cultivation. Journal of Bangladesh Agriculture University, 10 (2): 191195.

Chopra, N.K. and Chopra, N. (2004). Seed yield and quality of 'Pusa44' rice as influenced by nitrogen fertilizer and row spacing. Indian Journal Agricultural Sciences. 74 (3): 144- 146.

Devi, M. G. and Sumathi, V. (2011).Effect of nitrogen management on growth, yield and quality of scented rice (Oryza sativa L.) under aerobic conditions. Journal of Research ANGRAU, 39(3): 81-83.

Gupta, A.K., Jayasree, G. and Rani, Y.S. (2014).Effect of $\mathrm{N}$ levels on growth, yield and economics of aerobic rice. Progressive Research, 9(1): 130-132.

Mahato. P., Gunri. S. K., Chanda. K. and Ghosh.M. (2007). Effect of varying Levels of Fertilizer and Spacing on
Medium Duration Rice (Oryza Sativa L.) in Tarai Zone of West Bengal. Karnataka Journal Agricultural Science. 20(2): (363-365).

Mandal, S. S., Das Mahapatra, A. N. and Chatterjee, B. N. (1986). Effect of highrates of Potassium and Nitrogen on rice yield components. Environment and Ecology. 5: 300-303.

Miah M.H.N.,Karim M.A., Rahman M.S. and Islam M.S. (1990) Performance of Nizersail mutants under different row spacing. Bangladesh J. Train. Dev. 3(2): 31-34.

Mohadesi, A., Abbasian, A., Bakhshipour, S. and Aminpanah, H. (2011). Effect of different level of nitrogen and plant spacing on yield, yield components and physiological indices in High yield Rice. American- Eurasian journal agriculture and environmental science. 10 (5):893-900.

Namba, T. (2003). Optimum planting density and nitrogen application rate for maximizing rice yield. Crop Science Society of Japan. Japanese Journal of Crop Science. 72(2): 133-141.

Salahuddin, K. M., Chowhdury, S. H. Muniram, S., Islam, M.M. and Parvin, S. (2009). Response of nitrogen and plant spacing of transplanted aman rice (Oryza sativa L.) Bangladesh Journal Agril. Res. 34(2): 279-285.

Singh, K. N. and D. K. Sharma (1987). Response to nitrogen of rice in sodic soil. Inter. Rice Res. News Letter. 12(3): 45.

Singh, T., Shivay, Y.S. and Singh, S. (2004). Effect of date of transplanting and nitrogen levels on productivity and nitrogen use indices in hybrid and nonhybrid aromatic rice. Acta Agronomica Hungarica, 52(3): 245-252.

Tanaka A., Kawano K., Yamaguchi J. (1966). Photosynthesis, respiration, and plant type of the tropical rice plant. Int. Rice 
Res. Inst., Tech. Bull, 7.

Wang H.Q.(2007).Correlation between nitrogen application rate and the growth and development of hybrid rice. Fujian Journal of Agricultural Sciences, 22(3): 245-250.

Wells, B. R. and Faw. (1978). Short statured rice response to seedlings and nitrogen rates. Agronomy Journal. 70: 477-478. Yadav, A.S., Hardev Ram and Srivastava, D.S. (2016).Productivity of hybrid rice as affected by nitrogen levels and plant geometry under transplanted situation in eastern Uttar Pradesh. New Agriculturist, 27(1) : 125-134.

\section{How to cite this article:}

Pradeep Rajput, A. K.Singh, Ravindra Kumar Rajput and Prithvi Raj. 2020. Influence of Planting Geometry and Nitrogen Levels on Growth and Yield of Rice (Oryza Sativa L.) under Eastern Uttar Pradesh Condition. Int.J.Curr.Microbiol.App.Sci. 9(02): 2935-2941. doi: https://doi.org/10.20546/ijcmas.2020.902.334 